\title{
PENINGKATAN KETERAMPILAN MENULIS CERPEN DENGAN MENGGUNAKAN MEDIA LAGU SISWA KELAS VIII SMP MUHAMMADIYAH 1 TIDORE KEPULAUAN
}

\author{
Julianti Nyo ${ }^{1}$, Justam Wahab ${ }^{2}$, Rijal Muharam ${ }^{3}$ \\ 1,2,3 Program Studi Pendidikan Bahasa dan Sastra Indonesia, FKIP Universitas Khairun, Indonesia \\ julianti.nyo@gmail.com; justamwahab99@gmail.com; rijal.muharam12@gmail.com
}

\begin{abstract}
Abstrak
Penelitian ini dilakukan dengan tujuan (1) Untuk mengetahui apakah peningkatan keterampilan menulis cerpen dengan menggunakan media lagu siswa kelas VIII SMP Muhammadiyah 1 Tidore Kepulauan. (2) Untuk mengetahui bagaimanakah peningkatan keterampilan menulis cerpen dengan menggunakan media lagu siswa kelas VIII SMP Muhammadiyah 1 Tidore Kepulauan. Metode yang digunakan dalam penelitian ini adalah metode deskriptif kuantitatif. Populasi dalam penelitian ini adalah siswa kelas VIII SMP Muhammadiyah 1 Tidore Kepulauan sebanyak 25 siswa sedangkan sampel dalam penelitin ini merupakan keseluruhan dari jumlah populasi sebanyak 25 siswa sebesar 100\%. Hasil penelitian ini yaitu (1) Tes awal (pretest) siswa yang mendapatkan nilai yang masig kurang yaitu: kualifikasi sangat baik (SB) sebanyak 3 siswa sebesar $12 \%$, siswa yang mendapatkan kualifikasi baik (B) sebanyak 5 siswa sebesar $20 \%$, siswa yang mendapatkan kualifikasi cukup baik (CB) sebanyak 9 siswa sebesar $36 \%$, siswa yang mendapatkan kualifikasi kurang baik (KB) sebanyak 8 siswa sebesar 32\%, dan siswa yang mendapatkan kualifikasi kurang sekali (KS) sebanyak 0 siswa sebesar 0\%. (2) Tes akhir (posttest) siswa yang mendapatkan kualifikasi sangat baik (SB) sebanyak 8 siswa sebesar 32\%, siswa yang mendapatkan kualifikasi baik (B) sebanyak 11 siswa sebesar 44\%, siswa yang mendapatkan kualifikasi cukup baik (CB) sebanyak 4 siswa sebesar 16\%, siswa yang mendapatkan kualifikasi kurang baik (KB) sebanyak 2 siswa sebesar $8 \%$, dan siswa yang mendapatkan skor 1 kualifikasi kurang sekali (KS) sebanyak 0 siswa sebesar 0\%. Dengan demikian dapat disimpulkan bahwa siswa dengan menggunakan media lagu dapat meningkatkan ketrampilan menulis cerpen.
\end{abstract}

Kata Kunci: Menulis Cerpen, Media Lagu.

\begin{abstract}
This research was conducted with the aim of (1) to find out whether the improvement of short story writing skills using the media song of class VIII Muhammadiyah 1 Middle School Tidore Kepulauan. (2) To find out how to improve short story writing skills by using the media song of class VIII Muhammadiyah Middle School 1 Tidore Kepulauan. The method used in this research is quantitative descriptive method. The population in this study were grade VIII Muhammadiyah 1 Tidore Kepulauan Middle School as many as 25 students while the sample in this study was a total of 25 students as much as 100\%. The results of this study are (1) Observation, Indonesian language teachers have taught students with learning material to write short stories through using song media and the teacher has carried out the learning process well in accordance with the Learning Implementation Plan (RPP); (2) Interviews, students interested and happy with learning to write short stories using song media. Media songs are very helpful for them in determining the theme they will make short stories. The theme presented is about friendship that is unique to their world; (3) The initial test (pretest) of students who get very good qualifications (SB) is 3 students by 12\%, students who get good qualifications (B) as many as 5 students by 20\%, students who get quite good qualifications $(C B)$ as many as 9 students by 36\%, students who get poor qualifications (KB) as many as 8 students by $32 \%$, and students who get less qualifications (KS) as many as 0 students at $0 \%$. Has not yet achieved an increase in value; (4) Final test (posttest) of students who get very good qualifications (SB) as many as 8 students by $32 \%$, students who get good qualifications (B) as many as 11 students at $44 \%$, students who get quite good qualifications $(C B)$ as much as 4 students by $16 \%$, students who get poor qualifications (KB) as much as 2 students by 8\%, and students who get a score of 1 qualifier less (KS) as many as 0 students at $0 \%$. It means that the use of song can improve students' scoor in writing short story.
\end{abstract}

Key Words: Writing short stories, media songs 


\section{PENDAHULUAN}

Menulis adalah suatu kegiatan menuangkan ide atau gagasan dalam bentuk tulisan. Menulis merupakan salah satu cara untuk melegakan perasaan, juga sebagai pengungkapan diri. Menulis membutuhkan ketekunan, kesabaran dan keahlian berkata-kata agar apa yang ditulisnya dapat dipahami orang lain. Menulis merupakan suatu proses kreatif yang banyak melibatkan cara berpikir divergen (menyebar) daripada konvergen (memusat) siswa. Menulis tidak ubahnya dengan melukis, siswa memiliki banyak gagasan untuk dituangkan dalam tulisan. Menulis juga merupakan kebutuhan utama dalam proses transfer dan pengembangan ilmu pengetahuan. Keterampilan menulis adalah kemampuan menggunakan bahasa secara tertulis untuk menyampaikan informasi suatu peristiwa sehingga timbul komunikasi Morsey (dalam Tarigan, 2008: 4).

Keterampilan menulis cerpen bukanlah sesuatu yang dapat diajarkan melalui uraian atau penjelasan semata-mata. Siswa tidak dapat memperoleh keterampilan menulis hanya dengan duduk, mendengarkan penjelasan guru, dan mencatat penjelasan guru. Keterampilan menulis cerpen dapat ditingkatkan melalui kegiatan menulis cerpen secara terus menerus sehingga akan mempengaruhi hasil dan prestasi siswa dalam menulis cerpen. Hasil dan prestasi dapat meningkat apabila ada perubahan sikap dan tingkah laku siswa, baik pada aspek pengetahuan, keterampilan maupun psikomotorik.

Berdasarkan hasil observasi yang dilakukan peneliti pada siswa kelas VIII SMP Muhammadiyah 1 Tidore Kepulauan, ditemukan beberapa kendala dalam proses pembelajaran menulis cerpen yang ada di sekolah, antara lain keterbatasan buku penunjang, khususnya penulisan cerpen, kurangnya variasi media pembelajaran cerpen sehingga pembelajaran menjadi monoton, kesulitan yang dialami peserta didik dalam menentukan dan mengembangkan ide cerita, keterbatasan pengalaman pengajar dalam bidang cerpen, kurangnya minat siswa dalam pembelajaran cerpen, dan kurangnya alokasi waktu untuk pembelajaran cerpen di sekolah. Selain itu, siswa kurang mendapat motivasi dan dorongan untuk menulis. Kurangnya peranan guru mengakibatkan media, metode, dan teknik yang digunakan untuk pembelajaran menjadi kurang maksimal. Di samping itu, guru kurang kreatif dalam memilih media. Metode penyampaian guru yang dirasa sangat membosankan bagi siswa, bahkan menjadikan siswa tidak bergairah dengan materi penulisan cerpen. Dengan media lagu dirasa cukup efektif untuk mebuat pembelajaran terasa lebih ringan dan menyenangkan karena aktifitas pembelajaran dilakukan dengan mendengarkan lagu sehingga siswa tidak akan merasa bosan, dan mengantuk, tetapi akan lebih tertarik, bersemangat dalam memperhatikan pembelajaran, serta berani aktif saat proses pembelajaran (Utami, 2014: 2-3).

\section{Pengertian Menulis}

Menulis merupakan suatu kegiatan komunikasi berupa penyampaian (informasi) secara tertulis kepada pihak lain dengan menggunakan bahasa tulis sebagai alat atau medianya. Aktivitas menulis melibatkan beberapa unsur, yaitu: penulis sebagai penyampain pesan, isi tulisan, saluran atau media, dan pembaca. Dalam hal ini, seorang penulis harus memiliki keterampilan dalam menulis sehingaa pesan yang disampaikan dapat diterima dengan baik oleh pembaca melalui media tulisan (Dalman, 2015: 6).

\section{Pengertian Cerpen}

Cerita pendek adalah cerita berbentuk prosa yang relatif pendek. Ukuran pendek di sini dapat diartikan dengan cerita dapat di baca sekali duduk juga karena waktu kurang dari satu jam. 
Dikatakan pendek juga karena cerita ini hanya mempunyai efek tunggal, karakter, plot dan latar yang terbatas, tidak beragam dan tidak kompleks.

Dari aspek isi, cerpen adalah cerita fiksi yang penceritaannya memadat dan memusat pada satu peristiwa atau masalah ataupun pada satu tokoh dengan kesan tunggal. Dari aspek bentuk cerpen adalah cerita fiksi yang pendek, yang pada umumnya ditulis antara 1-30 halaman. Kertas folio dengan pengetikan spasi renggang atau terdiri antara 500-40.000 kata.

Cerpen adalah kisah pendek (kurang dari 10.000 kata) yang dimaksudkan memberikan kesan tunggal yang dominan, cerpen memusat pada satu tokoh dalam satu situasi pada suatu ketika, meskipun persyaratan ini tidak terpenuhi, cerpen yang efektif terdiri dari tokoh atau sekelompok tokoh lewat lakuan lahir atau batin terlibat dalam satu situasi tikaian dramatik, yaitu perbenturan antara kekuatan yang berlawanan merupakan inti cerpen Sudjiman (dalam Falestina, 2009: 24-25).

\section{Media Lagu}

Penggunaan media harus sejalan dengan tujuan pengajaran yang telah dirumuskan. Manakala tujuan pembelajaran diabaikan dalam menggunakan media maka bukan lagi sebagai alat bantu pengajaran, tetapi sebagai penghambat dalam pencapaian tujuan secara efektif dan efisien. Penggunaan media dalam proses belajar mengajar juga dapat membangkitkan rasa ingin tahu dan minat, membangkitkan motivasi, dan stimulus dalam proses belajar mengajar, serta dapat mempengaruhi psikologi siswa. Oleh karena itu, media dapat digunakan secara tepat, secara nyata membantu, dan mempermudah proses belajar mengajar. Dengan demikian, hasil pembelajaran dapat lebih optimal.

Lagu adalah bagian dari karya musik dan musik adalah salah satu bagian dari karya seni. Oleh karena itu, dapat dikatakan bahwa lagu adalah suara yang berirama dipadukan dengan ritmeritme tertentu dalam irama sehingga akan muncul beberapa jenis lagu, seperti keroncong, dangdut, pop, rock, dan jazz.

Pembelajaran menulis cerpen dengan menggunakan media lagu, yaitu menyoroti teks lagu tersebut dari tema dan alur. Dengan menyoroti dua hal tersebut media lagu dapat mempermudah siswa dalam memberi gambaran pengalaman orang lain yang akan dijadikan sebagai bahan dasar penulisan cerpen. Selain itu, penggunaan media lagu dalam pembelajaran menulis cerpen harus memiliki syarat. Syarat tersebut, yaitu (1) kesesuaian tema dengan usia. Artinya, tema yang dipilih harus sesuai dengan usia anak berdasarkan jenjang pendidikan, apakah itu siswa SD, SMP, atau SMA, (2) mempunyai alur cerita yang jelas, dan (3) lirik lagu harus berupa cerita sehingga memudahkan siswa dalam mengembangkan ide, gagasan, atau perasaannya (Falestina, 2009: 3940).

\section{METODE PENELITIAN}

Metode pengolahan data yang digunakan yaitu metode deskriptif kuantitatif yaitu data penelitian dianalisis melalui pengguraian angka-angka numerik statistik sesuai dengan data penelitian yang diperoleh dalam pembelajaran menulis cerpen dengan menggunakan media lagu.

Penelitian kuantitatif atau positivistik merupakan penelitian yang dilakukan untuk mendapatkan jawaban dari permasalahan atau gambaran umum tentang suatu fenomena atau gejala yang dilandasi pada teori, asumsi atau andaian, dalam hal ini dapat diartikan sebagai pola fikir yang menunjukkan hubungan antara variabel-varial yang akan diteliti, sekaligus mencerminkan jenis dan jumlah rumusan masalah yang perlu diwajibkan melalui penelitian, teori yang digunakan adalah untuk merumuskan hipotesis, dan teknik analisis statistik yang hendak digunakan (Iskandar, 2013: 17). 


\section{Desain Penelitian}

Desaian penelitian ini adalah desain one group pretest posttest (Sugiyono, 2016: 112). Prosedur yang dilakukan adalah seperti pada Gambar di bawah ini

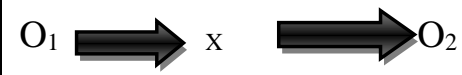

Gambar Desaian penelitian one group pretest posttest

\section{Keterangan:}

$\mathrm{O}_{1}$ : Pretest untuk mengukur kemampuan siswa dalam menulis cerpen dengan menggunakan media lagu

$\mathrm{X}$ : Penggunaan media lagu dalam pembelajaran menulis cerpen

$\mathrm{O}_{2}$ :Posttest untuk meningkatkan kemampuan siswa dalam menulis cerpen dengan menggunakan media lagu

Populasi dalam penelitian ini merupakan keseluruhan siswa kelas VIII SMP Muhammadiyah 1 Tidore Kepulauan sebanyak 25 siswa. Populasi adalah jumlah keseluruhan dari satuan-satuan atau individu-individu yang karakteristiknya hendak diduga (Gozali \& Nasehudin, 2015: 121). Sementara, sampel dalam penelitian merupakan keseluruhan dari jumlah pupolasi yang merupakan siswa kelas VIII SMP Muhammadiyah 1 Tidore Kepulauan, sebanyak 25 siswa sebesar $100 \%$. Apabila subjek kurang dari 100, lebih baik diambil semua sehingga penelitiannya merupakan penelitian populasi. Tetapi, jika jumlah subjeknya besar, dapat diambil antara $10-15 \%$ atau $20-25 \%$ atau lebih (Arikunto, 2006: 134).

Teknik yang digunkan untuk menganalisis data penelitian adalah teknik analisis deskriptif kuantitatif yaitu data penelitian dianalisis melalui pengguraian angka-angka statistik dalam bentuk tabel berdasarkan berhasil penelitian dalam pembelajaran menulis cerpen dengan menggunakan media lagu.

Analisis data merupakan kegiatan yang dilakukan oleh peneliti setelah data terkumpul. Analisis data penelitian kuantitatif adalah menggunakan analisis statistik (Iskandar, 2013: 182). Rumus yang digunakan peneliti untuk menghitung hasil penelitian dalam pembelajaran menulis cerpen dengan menggunakan media lagu yaitu.

$$
\mathrm{P}=\frac{F}{N} \times 100
$$

Keterangan:

$$
\begin{aligned}
& \mathrm{P} \quad: \text { Presentase } \\
& \mathrm{F} \text { : Frekuensi } \\
& \mathrm{N} \text { : Jumlah Responden } \\
& \text { 100: Bilangan tetap }
\end{aligned}
$$

\section{HASIL DAN PEMBAHASAN}

Hasil penelitian menulis cerpen dengan menggunakan media lagu diperoleh dari hasil tes dan nontes, dan terdiri atas tes awal (pretest) dan tes akhir (posttest). Selanjutnya hasil penelitian atau evaluasi pembelajaran pada tes awal (pretest) disempurnakan pada rancangan pembelajaran tes akhir (posttest) untuk meningkatkan hasil belajar siswa kelas VIII SMP Muhammadiyah 1 Tidore Kepulauan.

\section{Hasil Observasi}

Pengambilan data melalui observasi ini bertujuan untuk mengetahui perilaku siswa selama proses pembelajaran. Observasi dilakukan selama pembelajaran berlangsung. Pada saat proses pembelajaran masih ada siswa yang menunjukkan perilaku yang kurang menyenangkan, diantaranya masih ada yang mengobrol dengan temannya, memperhatikan keadaan di luar kelas dan masih ada yang duduk tidak dengan posisi yang benar. Meskipun dalam proses pembelajaran 
situasi masih belum kondusif, namun hasil yang dicapai oleh siswa cukup baik, siswa pun antusias dalam mengikuti pembelajaran menulis cerpen. Hal ini bisa diketahui dari respon siswa pada saat memperhatikan penjelasan dari guru serta menghayati contoh cerpen berdasarkan media lagu yang telah didengarkan.

Guru sedang menyampaikan pembelajaran menulis cerpen, menunjukkan sikap siswa yang belum terlihat serius mendengarkan penjelasan mengenai materi menulis cerpen menggunakan media lagu yang disampaikan oleh guru atau penulis. Masih ada beberapa siswa yang kurang memperhatikan penjelasan guru. Mereka masih bergurau atau mengobrol dengan teman, bahkan ada juga yang sibuk menulis yang tidak berhubungan dengan materi yang disampaikan. Mereka menganggap pembelajararan ini tidak penting.

Keaktifan siswa dalam mengikuti pembelajaran menulis cerpen dapat dilihat juga dari keberanian siswa pada sesi tanya jawab dengan guru. Sebanyak 5 siswa atau $20 \%$ dari jumlah keseluruhan siswa aktif dalam kegiatan tanya jawab. Sisanya sebanyak 20 siswa atau 80\% kurang aktif dalam kegiatan tanya jawab. Siswa yang kurang aktif dikarenakan mereka malu dan tidak percaya diri.

Sebanyak 22 siswa atau $88 \%$ dari jumlah keseluruhan siswa yang merespon positif ( senang ) terhadap contoh cerpen yang dibuat guru. Sisanya sebanyak 3 siswa atau $12 \%$ dari jumlah keseluruhan siswa yang tidak merespon positif terhadap contoh cerpen yang dibuat guru. Siswa yang merespon positif ditunjukkan dengan perilaku yang memperhatikan serius contoh cerpen yang dibuat oleh guru.

Sikap siswa saat membaca contoh cerpen berdasarkan lirik lagu yang disediakan. Contoh tersebut disertai kerangka tulisan supaya mempermudah siswa dalam membuat cerpen. Sebagian besar siswa terlihat serius dan menikmati contoh cerpen tersebut, tetapi ada pula beberapa siswa yang kurang peduli dengan contoh cerpen tersebut dan asyik mengobrol dengan temannya. Pembelajaran pada tes awal (pretest) ini belum terlihat efektif karena hari sudah terlalu siang dan para siswa sudah merasa malas dan mengantuk.

Sikap siswa terhadap media pembelajaran yang digunakan guru. Pada saat pembelajaran dengan menggunakan media lagu, sebanyak 25 siswa dari jumlah keseluruhan siswa atau 100\% merespon positif dengan media yang digunakan oleh guru. Mereka berpendapat bahwa mereka belum pernah diajarkan menulis cerpen dengan media yang digunakan oleh guru sebelumnya. Media yang digunakan mempermudah siswa dalam menemukan tema dan alur yang nantinya akan mereka tulis menjadi sebuah cerpen.

Keaktifan siswa saat mengerjakan tugas dari guru, yaitu menulis cerpen berdasarkan pengalaman pribadinya. Sebanyak 19 siswa atau 76\% sikap siswa pada saat menulis cerpen dengan penuh perhatian. Sisanya sebanyak 6 siswa atau 24\% kurang perhatian pada saat menulis cerpen. Hal ini dikarenakan mereka malas, tidak bersemangat, dan ingin cepat pulang, maka dari itu mereka tidak konsentrasi penuh dengan pembelajaran.

Siswa membacakan hasil karya mereka dalam membuat cerpen menggunakan media lagu. Hanya sedikit siswa saja yang mau membacakan hasil karya mereka di depan kelas. Siswa yang maju ke depan kelas cukup antusias membacakan hasil karya mereka yaitu menulis cerpen berdasarkan media lagu. Siswa yang lain memperhatikan dan memberikan komentarnya.

Data tersebut menunjukkan bahwa siswa memiliki sikap yang cukup baik dalam proses pembelajaran keterampilan menulis cerpen menggunakan media lagu. Namun, masih perlu dilakukan perbaikan dalam kegiatan pembelajaran untuk merubah siswa yang negatif menjadi positif.

Berdasarkan uraian di atas, dapat disimpulkan bahwa perilaku negatif siswa masih ada selama pembelajaran berlangsung. Meskipun jumlah siswa yang melakukan perilaku positif lebih 
banyak daripada perilaku negatif, tetapi masih perlu ditingkatkan lagi supaya siswa lebih aktif dan perilaku negatif yang muncul dalam pembelajaran dapat dikurangi pada proses pembelajaran berikutnya.

\section{Hasil Wawancara}

Hasil wawancara dalam penelitian ini diperoleh dari guru mata pelajaran bahasa Indonesia dan siswa kelas VIII SMP Muhammadiyah 1 Tidore Kepulauan, yaitu sebagai berikut:

\section{Hasil Wawancara Guru}

Hasil wawancara yang diperoleh dari guru mata pelajaran bahasa Indonesia yaitu: Pertama (1), Pernahkah siswa diajarkan dengan pembelajaran menulis cerpen? Ya, untuk materi menulis cerpen telah diajarkan kepada siswa. Materi pembelajaran menulis cerpen telah diajarkan kepada siswa karena pokok bahasan penulisan cerpen termuat dalam kurikulum pendidikan bahasa Indonesia sehingga guru wajib memberikan materi pembelajaran kepada siswa. Kedua (2), Bagaimana kesiapan siswa dalam mengikuti pembelajaran menulis cerpen? Siswa menyiapkan buku-buku pembelajaran dan datang ke sekolah tepat waktu, namun masih ada beberapa siswa yang suka datang terlambat. Siswa telah melakukan persiapan untuk mengikuti pembelajaran dengan baik melalui pelaksanaan pembelajaran dengan menyiapkan buku-buku pembelajaran untuk jadikan sebagai sumber belajar dan siswa juga datang tepat waktu sebelum materi pembelajaran dimulai.

Yang ketiga (3), Bagaimana keaktifan siswa dalam mengikuti pembelajaran menulis cerpen? Terdapat beberapa siswa yang aktif memberikan pertanyaan dalam belajar apabila terdapat materi-materi yang belum dipahami. Siswa telah memberikan respon aktif dalam belajar untuk menanyakan materi yang belum dipahami kepada guru bidang studi namun masih banyak siswa yang terlihat pasif atau tidak aktif mengikuti proses belajar mengajar sehingga guru menggunakan bimbingan belajar yang efektif dan inovatif agar meningkatkan kemampuan siswa. Keempat (4), Adakah faktor penghambat yang dialami siswa dalam pembelajaran menulis cerpen? Ya ada, siswa belum mampu menempatkan tanda baca dengan baik dalam penulisan. Siswa juga belum mampu memilih diksi atau pilihan kata yang tepat untuk menulis cerpen. Faktor penghambat yang dialami siswa dalam proses belajar mengajar dapat menghambat peningkatkan kualitas belajar sehingga guru menggunakan media, model, dan metode pembelajaran yang kreatif sesuai dengan masing-masing karakter siswa agar memecahkan masalah dalam belajar dan mampu meningkatkan pemahaman siswa untuk lebih giat dalam belajar. (5) Bagaimana respon siswa terhadap proses pembelajaran dengan media lagu? Siswa terlihat sangat antusias dengan menggunaan media lagu. Siswa aktif mengikuti proses belajar mengajar melalui penggunaan media lagu karena dengan mudah mereka mengembangkan gagasannya untuk dituangkan dalam karyanya berupa penulisan cerpen.

\section{Hasil Wawancara Siswa}

Hasil wawancara dengan siswa kelas VIII SMP Muhammadiyah 1 Tidore Kepulauan yaitu: (1) Apakah Anda senang saat mendapatkan pembelajaran menulis cerpen? Ya kami merasa senang dengan pembelajaran menulis cerpen yang diberikan oleh guru bidang studi. Siswa memberikan respon baik dengan materi pembelajaran menulis cerpen karena dapat menambahkan pengetahuan bagi mereka untuk membuat cerpen. (2) Apakah Anda mendapatkan kesulitan ketika menulis cerpen? Apa yang menjadi penyebab kesulitan tersebut? Kesulitan dalam hal menyusun kata-kata supaya menjadi sebuah cerpen yang enak dibaca dan juga masih ada yang kesulitan menyusun alurnya. Dari kesulitan yang dihadapi siswa guru dan peneliti melakukan kolaborasi dalam proses belajar mengajar untuk memberikan materi kepada siswa dengan menggunakan media dan metode 
pembelajaran yang efektif agar meningkatkan hasil belajar siswa. (3) Berikan saran Anda terhadap pembelajaran menulis cerpen melalui media lagu! Diharapkan kepada teman-teman agar lebih giat dalam belajar dan untuk guru mata pelajaran lebih efektif dalam menggunakan metode mengajar yang tepat. Adapan saran yang diberikan kepada siswa sebagai dorongan untuk meningkatkan kualitas pembelajaran khusus dalam menulis cerpen. (4) Apakah guru pernah memberikan tugas untuk menulis cerpen? Ya pernah. Guru telah memberikan siswa tugas untuk melatih kemampuan siswa dalam mengembangkan potensinya untuk mengarang. (5) Bagaimanakah cara mengajar gurumu dalam memberikan materi pembelajaran menulis cerpen? Cara mengajar guru sangat baik. Siswa memberikan apresiasi terhadap proses pelaksanaan pembelajaran yang diberikan oleh guru mata pelajaran dengan menjelaskan materi secara rinci sehingga dengan mudah dipahami siswa.

Hasil Tes Awal (Pretest) Keterampilan Menulis Cerpen dengan Menggunakan Media Lagu

Tabel 1. Rekapitulasi Hasil Penilaian pada Tes Awal (Pretest)

\begin{tabular}{|c|c|c|c|c|c|c|c|c|c|}
\hline \multirow[t]{2}{*}{ No } & \multirow[t]{2}{*}{ Nama Siswa } & \multicolumn{5}{|c|}{$\begin{array}{c}\text { Aspek Penilaian dalam } \\
\text { Menulis Cerpen dengan Media } \\
\text { Lagu }\end{array}$} & \multirow[t]{2}{*}{$\begin{array}{l}\text { Total } \\
\text { Skor }\end{array}$} & \multirow[t]{2}{*}{ Nilai } & \multirow[t]{2}{*}{ Kualifikasi } \\
\hline & & $\mathbf{1}$ & 2 & 3 & 4 & 5 & & & \\
\hline 1 & Siti Khadija Muksin & 5 & 3 & 2 & 3 & 3 & 16 & 64 & $\mathrm{~KB}$ \\
\hline 2 & Julita Abdullah & 5 & 2 & 2 & 3 & 3 & 15 & 60 & KB \\
\hline 3 & Ibnu Al-Afarid & 5 & 4 & 3 & 4 & 3 & 19 & 76 & B \\
\hline 4 & Nurul Fitri Abubakar & 5 & 3 & 2 & 2 & 2 & 14 & 56 & KB \\
\hline 5 & Susmita Samsudin & 4 & 3 & 2 & 3 & 2 & 14 & 56 & KB \\
\hline 6 & Sumira Kamarudin & 5 & 3 & 2 & 4 & 3 & 17 & 68 & $\mathrm{CB}$ \\
\hline 7 & Nurawin Irwan & 3 & 3 & 2 & 3 & 3 & 14 & 56 & KB \\
\hline 8 & Zulfikar Dj. Marsaoli & 5 & 4 & 3 & 3 & 3 & 18 & 72 & $\mathrm{CB}$ \\
\hline 9 & Yulia Ningsih & 5 & 3 & 2 & 4 & 3 & 17 & 68 & CB \\
\hline 10 & Suhaimi Najamudin & 5 & 5 & 4 & 5 & 5 & 24 & 96 & SB \\
\hline 11 & Sabrin A. Togubu & 4 & 3 & 2 & 3 & 3 & 15 & 60 & KB \\
\hline 12 & Arseti Patty & 3 & 3 & 2 & 4 & 2 & 14 & 56 & KB \\
\hline 13 & Sukmawati Wahab & 5 & 4 & 5 & 3 & 3 & 20 & 80 & B \\
\hline 14 & Alaudin A.M Usman & 4 & 3 & 2 & 4 & 3 & 16 & 64 & KB \\
\hline 15 & Aolia Qur Rama. Y & 5 & 4 & 3 & 3 & 3 & 18 & 72 & $\mathrm{CB}$ \\
\hline 16 & Buyung M.S Sahrial & 5 & 3 & 3 & 4 & 3 & 18 & 72 & $\mathrm{CB}$ \\
\hline 17 & $\begin{array}{l}\text { Daniela M. Padang } \\
\text { Yusuf }\end{array}$ & 5 & 4 & 3 & 5 & 4 & 21 & 84 & B \\
\hline 18 & Ayu Sufi Musaki & 5 & 3 & 2 & 4 & 3 & 17 & 68 & $\mathrm{CB}$ \\
\hline 19 & Alya Amin & 5 & 4 & 3 & 4 & 3 & 19 & 76 & B \\
\hline 20 & M. Rifaizal Saiful & 5 & 3 & 3 & 3 & 3 & 17 & 68 & $\mathrm{CB}$ \\
\hline 21 & Anisa Bayau & 5 & 5 & 4 & 4 & 4 & 22 & 88 & SB \\
\hline 22 & Armin Lutfi & 4 & 3 & 3 & 4 & 3 & 17 & 68 & $\mathrm{CB}$ \\
\hline 23 & $\begin{array}{l}\text { Muhammad S. } \\
\text { Tamsach }\end{array}$ & 5 & 4 & 3 & 4 & 4 & 20 & 80 & B \\
\hline 24 & $\begin{array}{l}\text { M. Risky Hasan } \\
\text { Arsyad }\end{array}$ & 5 & 3 & 3 & 4 & 3 & 18 & 72 & CB \\
\hline 25 & Fahrul Nurdin & 5 & 5 & 4 & 5 & 4 & 23 & 92 & SB \\
\hline \multicolumn{2}{|c|}{ Jumlah } & 117 & 87 & 69 & 92 & 78 & 443 & 1772 & \\
\hline \multicolumn{2}{|c|}{ Rata-rata } & 4,68 & 3,48 & 2,76 & 3,68 & 3,12 & 17,72 & 70,88 & \\
\hline
\end{tabular}


Berdasarkan tabel 1, rekapitulasi hasil penilaian pada tes awal (pretest) dalam pembelajaran menulis cerpen dengan menggunakan media lagu siswa belum mencapai peningkatan nilai sehingga diperlukan tindakan penelitian pada tahap berikutnya untuk meningkatkan hasil belajar siswa dalam penulisan cerpen pada mata pelajaran bahasa Indonesia, maka dapat diketahui siswa yang mendapatkan kualifikasi sangat baik (SB) sebanyak 3 siswa sebesar 12\%, siswa sangat mampu menulis cerpen dengan baik sesuai kaidah dan struktur penulisan cerpen, siswa yang mendapatkan kualifikasi baik (B) sebanyak 5 siswa sebesar 20\%, siswa mampu menulis cerpen dengan baik dan mampu menempatkan ejaan dan tanda baca dengan tepat sesuai kaidah kebakuan bahasa, siswa yang mendapatkan kualifikasi cukup baik (CB) sebanyak 9 siswa sebesar 36\%, siswa cukup mampu menulis cerpen namun kurang memperhatikan kaidah penulisan sehingga terdapat kesalahan pengguraian kosa kata dan tanda baca, siswa yang mendapatkan kualifikasi kurang baik (KB) sebanyak 8 siswa sebesar 32\%, siswa belum mampu menulis cerpen dengan baik sehingga hasil penulisannya tidak terstruktur sesuai kaidah dan tata bahasa penulisan cerpen yang tepat, dan siswa yang mendapatkan kualifikasi kurang sekali (KS) sebanyak 0 siswa sebesar $0 \%$. Pembelajaran menulis cerpen dengan menggunakan media lagu belum mencapai peningkatan nilai sehingga peneliti melanjutkan proses pelaksanaan penelitian pada tes akhir (posttest) pada uraian di bawah ini.

Hasil Tes Akhir (Postest) Keterampilan Menulis Cerpen dengan Menggunakan Media Lagu Tabel 2. Rekapitulasi Hasil Penilaian pada Tes Akhir (Postest)

\begin{tabular}{|c|c|c|c|c|c|c|c|c|c|}
\hline \multirow[t]{2}{*}{ No } & \multirow[t]{2}{*}{ Nama Siswa } & \multicolumn{5}{|c|}{$\begin{array}{l}\text { Aspek Penilaian dalam Menulis } \\
\text { Cerpen dengan Media Lagu }\end{array}$} & \multirow{2}{*}{$\begin{array}{l}\text { Total } \\
\text { Skor }\end{array}$} & \multirow[t]{2}{*}{ Nilai } & \multirow[t]{2}{*}{ Kualifikasi } \\
\hline & & 1 & 2 & 3 & 4 & 5 & & & \\
\hline 1 & Siti Khadija Muksin & 5 & 5 & 3 & 4 & 4 & 21 & 84 & B \\
\hline 2 & Julita Abdullah & 5 & 4 & 3 & 4 & 4 & 20 & 80 & B \\
\hline 3 & Ibnu Al-Afarid & 5 & 5 & 4 & 5 & 5 & 24 & 96 & SB \\
\hline 4 & $\begin{array}{l}\text { Nurul Fitri } \\
\text { Abubakar }\end{array}$ & 5 & 4 & 3 & 4 & 3 & 19 & 76 & B \\
\hline 5 & Susmita Samsudin & 5 & 3 & 2 & 3 & 3 & 16 & 64 & KB \\
\hline 6 & Sumira Kamarudin & 5 & 4 & 5 & 5 & 4 & 23 & 92 & SB \\
\hline 7 & Nurawin Irwan & 5 & 4 & 5 & 4 & 4 & 22 & 88 & SB \\
\hline 8 & $\begin{array}{l}\text { Zulfikar Dj. } \\
\text { Marsaoli }\end{array}$ & 5 & 4 & 4 & 4 & 3 & 20 & 80 & B \\
\hline 9 & Yulia Ningsih & 5 & 4 & 3 & 4 & 3 & 19 & 76 & B \\
\hline 10 & Suhaimi Najamudin & 5 & 5 & 4 & 5 & 5 & 24 & 96 & SB \\
\hline 11 & Sabrin A. Togubu & 5 & 3 & 2 & 3 & 3 & 16 & 64 & KB \\
\hline 12 & Arseti Patty & 5 & 4 & 3 & 3 & 4 & 19 & 76 & B \\
\hline 13 & Sukmawati Wahab & 5 & 4 & 4 & 5 & 5 & 23 & 92 & SB \\
\hline 14 & $\begin{array}{l}\text { Alaudin A.M } \\
\text { Usman }\end{array}$ & 5 & 3 & 2 & 3 & 4 & 17 & 68 & $\mathrm{CB}$ \\
\hline 15 & Aolia Qur Rama. Y & 5 & 4 & 3 & 3 & 4 & 19 & 76 & B \\
\hline 16 & Buyung M.S Sahrial & 5 & 3 & 3 & 3 & 3 & 17 & 68 & $\mathrm{CB}$ \\
\hline 17 & $\begin{array}{l}\text { Daniela M. Padang } \\
\text { Yusuf }\end{array}$ & 5 & 5 & 4 & 4 & 5 & 23 & 92 & SB \\
\hline 18 & Ayu Sufi Musaki & 5 & 4 & 3 & 3 & 3 & 18 & 72 & $\mathrm{CB}$ \\
\hline 19 & Alya Amin & 5 & 4 & 3 & 4 & 4 & 20 & 80 & B \\
\hline 20 & M. Rifaizal Saiful & 5 & 4 & 4 & 3 & 3 & 19 & 76 & B \\
\hline 21 & Anisa Bayau & 5 & 4 & 5 & 4 & 3 & 21 & 84 & $\mathrm{~B}$ \\
\hline 22 & Armin Lutfi & 5 & 3 & 4 & 3 & 4 & 19 & 76 & B \\
\hline 23 & Muhammad S. & 5 & 5 & 4 & 4 & 4 & 22 & 88 & SB \\
\hline
\end{tabular}




\begin{tabular}{|l|l|c|c|c|c|c|c|c|c|}
\hline & Tamsach & & & & & & & & \\
\hline 24 & $\begin{array}{l}\text { M. Risky Hasan } \\
\text { Arsyad }\end{array}$ & 5 & 3 & 3 & 3 & 4 & 18 & 72 & CB \\
\hline 25 & Fahrul Nurdin & 5 & 5 & 4 & 4 & 5 & 23 & 92 & SB \\
\hline Jumlah & 125 & 100 & 87 & 94 & 96 & 502 & 2008 & \\
\hline Rata-rata & 5,00 & 4,00 & 3,48 & 3,76 & 3,84 & 20,08 & 80,32 & \\
\hline
\end{tabular}

Berdasarkan tabel 2, pembelajaran menulis cerpen dengan menggunakan media lagu pada tes akhir (posttest) siswa telah mencapai peningkatan nilai dalam pembelajaran bahasa Indonesia, maka dapat diketahui siswa yang mendapatkan kualifikasi sangat baik (SB) sebanyak 8 siswa sebesar 32\%, siswa sangat mampu menulis cerpen dengan baik sesuai kaidah penulisan yang tepat, siswa yang mendapatkan kualifikasi baik (B) sebanyak 11 siswa sebesar 44\%, siswa mampu menulis cerpen dengan baik sesuai struktur penulisan dengan menggunakan bahasa baku, siswa yang mendapatkan kualifikasi cukup baik (CB) sebanyak 4 siswa sebesar 16\%, siswa cukup mampu menulis cerpen namun masih terdapat kesalahan penempatan tanda baca yang kurang tepat dan pemilihan diksi yang kurang menarik sehingga berpengaruh terhadap isi cerpen yang ditulis, siswa yang mendapatkan kualifikasi kurang baik (KB) sebanyak 2 siswa sebesar $8 \%$, siswa belum mampu menulis cerpen dengan baik sehingga hasil tulisannya tidak menarik untuk dibaca, dan siswa yang mendapatkan skor 1 kualifikasi kurang sekali (KS) sebanyak 0 siswa sebesar $0 \%$ dalam menulis cerpen dengan menggunakan media lagu. Di bawah ini akan dijelaskan hasil perbandingan nilai tes awal (pretest) dan tes akhir (posttest) dalam menulis cerpen dengan menggunakan media lagu.

\section{Pembahasan}

Peningkatan perilaku siswa dalam menulis cerpen merupakan bukti bahwa pembelajaran dengan menggunakan media lagu dapat menumbuhkan motivasi belajar siswa, meningkatkan pemahaman, dan kreativitas siswa. Peningkatan keterampilan menulis cerpen siswa ini juga diikuti oleh perubahan perilaku siswa dari tes awal (pretest) ke tes akhir (posttest). Dari hasil nontes yang berupa observasi dan wawancara dapat disimpulkan bahwa kesiapan siswa dalam mengikuti pembelajaran menulis cerpen dengan menggunakan media lagu masih kurang dan belum memuaskan. Beberapa siswa masih menunjukkan perilaku negatif. Namun pada tes akhir (posttest) dapat diketahui perubahan perilaku siswa terhadap penggunaan media lagu dalam pembelajaran menulis cerpen yang telah dilakukan berubah menjadi lebih baik.

Hasil proses pelaksanaan pembelajaran menunjukkan bahwa ada beberapa siswa yang belum serius mengikuti kegiatan belajar mengajar dengan baik. Saat proses pembelajaran berlangsung ada siswa yang sibuk sendiri dengan memainkan alat tulis dan mengobrol dengan temannya. Siswa kurang terlibat aktif dalam kegiatan tanya jawab. Saat peneliti melontarkan pertanyaan, siswa cenderung pasif. Siswa masih belum berani mengungkapkan pendapatnya, siswa masih malu dan takut salah dalam berpendapat. Ada beberapa siswa yang ke luar ruangan dalam waktu yang cukup lama dan mengantuk di dalam kelas. Saat mengerjakan tugas menulis cerpen, ada siswa yang melihat pekerjaan temannya karena belum yakin dengan kemampuan yang dimilikinya. Pada tes akhir (posttest) terjadi perubahan perilaku ke arah positif. Lebih siap dan terlibat aktif dalam proses pembelajaran. Saat peneliti melontarkan pertanyaan, siswa tidak lagi malu-malu, sebagian besar siswa sudah berani mengungkapkan pendapatnya tanpa ditunjuk terlebih dahulu oleh peneliti. Tidak ada siswa yang ke luar ruangan dan mengantuk di dalam kelas.

Pada tes awal (pretest) ada beberapa siswa yang terlihat kesulitan dalam mengembangkan cerita dan menuangkan ide mereka dalam cerpen, kemudian siswa tersebut meminta peneliti untuk membantu memecahkan masalah yang ia temukan. Namun, ada juga siswa yang terlihat bingung 
tetapi tidak berani untuk bertanya pada peneliti sehingga peneliti harus datang sendiri kepada siswa yang masih terlihat bingung ketika menulis cerpen. Tes akhir (posttest) saat siswa mengerjakan tugas menulis cerpen, peneliti berkeliling untuk mengontrol siswa jika mengalami kesulitan. Dengan demikian, siswa lebih leluasa dan lebih berani untuk bertanya pada peneliti jika mereka mengalami kesulitan.

Hasil tes yang dicapai pada tes akhir (posttest) yaitu siswa yang mendapatkan kualifikasi sangat baik (SB) sebanyak 8 siswa sebesar 32\%, siswa yang mendapatkan kualifikasi baik (B) sebanyak 11 siswa sebesar 44\%, siswa yang mendapatkan kualifikasi cukup baik (CB) sebanyak 4 siswa sebesar 16\%, siswa yang mendapatkan kualifikasi kurang baik (KB) sebanyak 2 siswa sebesar $8 \%$, dan siswa yang mendapatkan kualifikasi kurang sekali (KS) sebanyak 0 siswa sebesar $0 \%$ dengan nilai rata-rata sebesar $80,32 \%$ dalam menulis cerpen.

Berdasarkan analisis data dan situasi pembelajaran tersebut, dapat disimpulkan bahwa perilaku siswa dalam mengikuti pembelajaran mengalami perubahan ke arah yang lebih baik. Siswa semakin aktif dan termotivasi dalam belajar tanpa terbebani dan tidak ada tekanan karena mereka merasa senang. Dengan teknik dan media yang peneliti gunakan, siswa dapat belajar dengan santai. Selain itu, belajar menulis cerpen melalui media lagu sangat menarik karena memudahkan siswa dalam menulis cerpen yang baik.

\section{SIMPULAN}

Berdasarkan hasil penelitian dan pembahasan, maka dapat disimpulkan sebagai berikut:

1. Observasi, guru bahasa Indonesia telah mengajarkan siswa dengan materi pembelajaran menulis cerpen melalui menggunakan media lagu dan guru telah melaksanaan proses pembelajaran dengan baik sesuai dengan Rencana Pelaksanaan Pembelajaran (RPP);

2. Wawancara, siswa berminat dan senang dengan pembelajaran menulis cerpen menggunakan media lagu. Media lagu sangat membantu mereka dalam menentukan tema yang akan mereka jadikan cerpen. Tema yang disuguhkan yaitu mengenai persahabatan yang khas dengan dunia mereka;

3. Tes awal (pretest) siswa yang mendapatkan kualifikasi sangat baik (SB) sebanyak 3 siswa sebesar 12\%, siswa yang mendapatkan kualifikasi baik (B) sebanyak 5 siswa sebesar 20\%, siswa yang mendapatkan kualifikasi cukup baik (CB) sebanyak 9 siswa sebesar 36\%, siswa yang mendapatkan kualifikasi kurang baik (KB) sebanyak 8 siswa sebesar 32\%, dan siswa yang mendapatkan kualifikasi kurang sekali (KS) sebanyak 0 siswa sebesar 0\%. Belum mencapai peningkatan nilai;

4. Tes akhir (posttest) siswa yang mendapatkan kualifikasi sangat baik (SB) sebanyak 8 siswa sebesar 32\%, siswa yang mendapatkan kualifikasi baik (B) sebanyak 11 siswa sebesar 44\%, siswa yang mendapatkan kualifikasi cukup baik (CB) sebanyak 4 siswa sebesar 16\%, siswa yang mendapatkan kualifikasi kurang baik (KB) sebanyak 2 siswa sebesar 8\%, dan siswa yang mendapatkan skor 1 kualifikasi kurang sekali (KS) sebanyak 0 siswa sebesar 0\%. Mencapai peningkatan nilai.

\section{DAFTAR PUSTAKA}

Arikunto, Suharsimi. 2006. Prosedur Penelitian suatu Pendekatan Praktik. Jakarta: PT Rineka Cipta.

Dalman. 2015. Penulisan Populer. PT RajaGrafindo Persada: Jakarta

Falestina, Amnah. 2009. Peningkatan Keterampilan Menulis Cerpen Melalui Metode SugestiImajinasi Media Lagu Siswa Kelas X MA Salafiyah Karang Tengah Kabupaten Pemalang. Semarang: Universitas Negeri Semarang. 
Gozali, Nanang, \& Nasehudin, Syatori, Toto. 2015. Metode Penelitian Kuantitatif. Bandung: Pustaka Setia.

Iskandar. 2009. Penelitian Tindakan Kelas. UIN: Malang Press.

Kantor Bahasa, Maluku Utara. 2015. Jangan Jual Laut Kami. Ternate: Kantor Bahasa Maluku Utara Kemendikbud.

Kirana, Zahra, Dita. 2014. Keefektifan Penggunaan Media Lagu pada Pembelajaran Keterampilan Berbicara Bahasa Jerman Peserta Didik Kelas X di Madrasah Aliyah Negeri Purworejo. Yogyakarta: Universitas Negeri Yogyakarta.

Mahmud. 2011. Metode Penelitian Pendidikan. Bandung: CV Pustaka Setia.

Notoatmodjo, Soekidjo. 2002. Metode Penelitian Kesehatan. Jakarta: PT Rineka Cipta.

Nurudin. 2010. Dasar-dasar Penulisan. Malang: UMM Press.

Ridwan, \& dkk. 1991. Pembinaan Kemampuan Menulis Bahasa Indonesia. Jakarta: Erlangga.

Sugiyono. 2016. Metode Penelitian Pendidikan Pendekatan Kuantitatif, Kualitatif, dan R\&D. Bandung: Alfabeta.

Tarigan, Henry, Guntur. 2008. Menulis sebagai suatu Keterampilan Berbahasa. Bandung: Angkasa.

Utami, Tri, Sumber. 2014. Naskah Publikasi Penggunaan Media Lagu (Nyanyian) Untuk Meningkatkan Minat Belajar Siswa pada Mata Pelajaran IPA Kelas IV SD Negeri Tlogopandogan 2 Kecamatan Gajah Kabupaten Demak Tahun Ajaran 2013/2014. Surakarta: Universitas Muhammadiyah.

Windi, Caka, Carissa. 2013. Peningkatan Keterampilan Menulis Cerpen Menggunakan Model Pembelajaran Demonstrasi Sunyi dengan Memanfaatkan Lirik Lagu pada Siswa Kelas XII S1 SMA Negeri 1 Depok. Yogyakarta: Universitas Negeri Yogyakarta. 